\title{
THE ANALYSIS OF CARBON DIOXIDE EMISSIONS FROM TAIWAN'S EXPORT INDUSTRY
}

\author{
LIN, H. C. ${ }^{1}-$ ZHANG, W. H. ${ }^{2}-$ TSAI, K. H. ${ }^{3}-$ CHOU, L. C. ${ }^{4 *}$ \\ ${ }^{I}$ Department of Applied Economics, National Chiayi University, 600 Chiayi, RO China \\ ${ }^{2}$ School of Politics and Economics, King's College London, WC2R 2LS London, UK \\ ${ }^{3}$ Center of Economic Forecasting, Chung-Hua Institution for Economic Research, 114 Taipei, \\ RO China
}

${ }^{4}$ Department of Economics, Wenzhou Business College, 325000 Wenzhou, PR China

*Corresponding author

e-mail: zlc@wzbc.edu.cn

(Received 28 $8^{\text {th }}$ Mar 2019; accepted 22 $2^{\text {nd }}$ May 2019)

\begin{abstract}
By reviewing Taiwan's economic development after the Second World War, economic activities at various stages are driven by international trade exports, which has led to Taiwan's economic growth and rising per capita income. Therefore, the situation of Taiwan's export industry is of great significance to its development. In this study, the Environmental Input-Output (EIO) model, the World Input-Output Database (WIOD), and Socio-Economic Accounts are used to investigate the $\mathrm{CO}_{2}$ emissions of Taiwan's export industry sectors and its relationship with other countries. It is analysed how particular export sectors cause carbon dioxide emissions in domestic production supply chains (by tracking downstream to upstream), and how carbon emissions in specific sectors affect export output. The empirical results show that the growth rate of $\mathrm{CO}_{2}$ emissions in Taiwan's export industry is roughly the same as its GDP growth rate and far lower than Japan and the United States. From the perspective of industry categories, water transport, chemical products and electronic optical products are Taiwan's export sectors with high $\mathrm{CO}_{2}$ emissions and rapid growth.

Keywords: environmental input-output (EIO) model, Taiwan export sector, GDP, emission growth rate, supply chain
\end{abstract}

\section{Introduction}

With island-type economy and poor natural resources, Taiwan takes the exportoriented trade as the most important industry under the government's pursuit of industrial development. At the end of the 20th century, with the development of the Internet and the commercial application of new technologies, the cost of transnational operations of enterprises declined, and information systems made transnational supply chains and management more convenient. As China and Taiwan joined the WTO successively in 2001 and 2002, global trade has become increasingly more achievable under the globalization trend and the elimination of WTO trade barriers. In the past, most of the global trade was concentrated in the North American and EU markets, while in recent years, with the rise of Chinese economy and the expansion of the ASEAN (Association of Southeast Asian Nations) from the first four countries to ten countries, as well as the signing of the Free Trade Agreement (FTA), the focus of trade around the world has been shifted to the Asian region.

In recent years, as China's economy has shown a fast-growing trend for a long term, the open-door policy will inevitably deepen its dependence on international 
market (Lu, 2018). Thus, many Taiwanese businessmen have gone to the mainland to invest in the local development (Lin and Yang, 2017; Rigger, 2015), and the industrial division of labor between Taiwan and mainland has shown a weakening vertical division and a more common horizontal division. The proportion of Taiwan's export products in Table 1 shows that the first major export products in Taiwan are electronic components, and the proportion has increased year by year, reaching $33 \%$ in 2016. The second is audio-visual products, accounting for about $10 \%$ in the past ten years. The third is metal products, the proportion of which continues to decline, and the proportions of mineral products, petroleum refining products and textiles have also declined due to the change in industrial structure.

Table 1. Structure of Taiwan's export products (unit: \%)

\begin{tabular}{c|c|c|c|c|c|c|c|c|c|c}
\hline & $\mathbf{2 0 0 7}$ & $\mathbf{2 0 0 8}$ & $\mathbf{2 0 0 9}$ & $\mathbf{2 0 1 0}$ & $\mathbf{2 0 1 1}$ & $\mathbf{2 0 1 2}$ & $\mathbf{2 0 1 3}$ & $\mathbf{2 0 1 4}$ & $\mathbf{2 0 1 5}$ & $\mathbf{2 0 1 6}$ \\
\hline Electronic components & 22.2 & 21.4 & 24.3 & 24.9 & 24.1 & 24.5 & 25.9 & 28.2 & 30.1 & 33.1 \\
Audio-visual products & 11.6 & 10.0 & 10.5 & 11.2 & 11.7 & 10.3 & 10.0 & 9.7 & 10.7 & 10.8 \\
Metal products & 11.2 & 11.0 & 9.4 & 9.4 & 9.7 & 9.2 & 8.9 & 9.1 & 8.9 & 8.8 \\
Mechanical products & 7.1 & 7.0 & 6.1 & 6.7 & 7.2 & 7.3 & 6.9 & 7.2 & 7.5 & 7.5 \\
Plastic rubber products & 7.6 & 7.7 & 8.1 & 8.0 & 8.1 & 7.9 & 8.0 & 7.6 & 7.4 & 7.1 \\
Chemical products & 6.0 & 6.8 & 6.9 & 7.0 & 7.3 & 6.9 & 7.0 & 6.9 & 6.4 & 6.1 \\
Optical equipment & 7.1 & 7.6 & 6.9 & 7.6 & 6.7 & 6.7 & 6.3 & 5.6 & 4.5 & 4.1 \\
Mineral products & 5.7 & 7.4 & 5.7 & 5.3 & 5.8 & 7.3 & 7.8 & 6.7 & 4.2 & 3.9 \\
Petroleum refining products & 5.4 & 7.0 & 5.3 & 5.0 & 5.5 & 6.9 & 7.3 & 6.2 & 3.6 & 3.4 \\
Motor products & 6.9 & 6.2 & 5.7 & 5.2 & 4.0 & 4.2 & 4.4 & 4.1 & 4.1 & 3.4 \\
Conveyance & 3.2 & 3.5 & 3.8 & 3.4 & 3.3 & 3.6 & 3.5 & 4.1 & 4.1 & 3.9 \\
Textiles & 4.7 & 4.2 & 4.5 & 4.1 & 4.1 & 3.9 & 3.8 & 3.8 & 3.8 & 3.5 \\
\hline
\end{tabular}

Data source: National Statistics, R.O.C. (Taiwan)

Intermediate goods of various semi-finished products and components account for a high proportion of Taiwan's exports, which are combined with the production factors of exporting countries and sold around the world. In other words, the various interdependent items in international trade form an industrial chain. Nowadays, countries all over the world are developing industrial structures, adjusting economic physique, and claiming to comprehensively improve the self-made rate (Meng et al., 2017; Ritchie et al., 2018), then if Taiwan cannot upgrade its industrial structure and develop an "independent economy" model, it will inevitably be affected by a strong economic impact. The development trend of global trade is particularly significant in the vertical division of labor. The international vertical division of labor is the multinationalization of production process, so that the final production of goods is completed through different manufacturing processes in many countries. In Taiwan, the production of components relies on the import of raw materials, which will generate carbon dioxide $\left(\mathrm{CO}_{2}\right)$ in the production process. Therefore, this paper intends to understand how much carbon dioxide emissions are generated due to exports, and to explore the correlation analysis of how the downstream export industry can drive carbon dioxide emissions from domestic upstream industry.

This paper explores the comparison of $\mathrm{CO}_{2}$ emissions between industries in Taiwan and its major exporting countries, and uses the Environmental Input-Output 
(EIO) model to provide an in-depth understanding of the sources and structures of $\mathrm{CO}_{2}$ emissions from the countries. Based on the above research motivation, the main purpose of this paper is to understand the industrial input-output structure and industrial linkage profile of each country according to the input-output tables from the World Input-Output Database (WIOD). The Socio-Economic Accounts from 1995 to 2011, and the old and new versions of WIOD from 1995 to 2011 and from 2000 to 2014 are used to analyze and compare the change in the trends of $\mathrm{CO}_{2}$ emissions from industrial exports in countries under the global value chain.

\section{Literature review}

There are four types of assessment methods for the impact of international trade on the environment in the literature. The first type is Structural Path Analysis (SPA), which refers to the use of input-output analysis to track complex production processes under given final demands. The traditional SPA method only explores one single region, and if the upstream and downstream industrial chains of a product belong to different countries, it will be impossible to discuss the single affiliation problem, such as Lenzen (2003), Peter and Hertwich (2006); the second type is Hybrid Input-Output Analysis, which refers to the use of input-output tables composed of price units and material units to distinguish energy from non-energy, such as Kagawa and Inamura (2001), Dietzenbacher and Stage (2006).

The third type is Multi-regional Input-Output Analysis (MRIO), which refers to that the single-region input-output table is estimated and broken down into a multiregion input-output table under the traditional SPA model framework, so as to calculate the industrial correlation effects on output and pollution emissions in various regions through the final demand and correlation matrix of each region. Since the unit output value, output and even proportion are required for the use of mixed unit model, the difficulty of data collection is a major shortcoming, such as Lenzen et al. (2004), Peter and Hertwich (2006). The fourth type is the EIO model, that is, the use of multi-regional input-output method to extend the regional model derived from the environmental coefficient, so as to gain a deeper understanding of the sources and structures of carbon dioxide emissions from countries' exports and explore climate policies regarding carbon leakage formulated by various countries.

In the past literature, Peter and Hertwich (2006) used the SPA method and the MRIO method to explore the environmental impact brought by the Norwegian international trade. The results show that in terms of household consumption, $80 \%$ of the direct emissions of personal fuels environmental impact are the transportation consumption of the households. In the government consumption sector, government expenditures are mainly in the medical treatment, education, and public administration departments, whose public sector has a greater impact on the purchase of transportation vehicles. If compared with households and export sectors, the government's pollution discharge density is relatively low.

Jin et al. (2017) analyzes a few scenarios of Korean CCS projects with a $\mathrm{CO}_{2}$ pipeline transportation network optimization model for minimizing the total facility cost and pipeline cost. The results for each scenario demonstrate that the effective design and implementation of $\mathrm{CO}_{2}$ pipeline network enables the lowering of $\mathrm{CO}_{2}$ units cost. Liu et al. (2016) analyzed the impact of corporate heterogeneity by using 
the EIO model, and found that ignoring corporate heterogeneity may lead to overestimation of carbon dioxide emissions from China's export.

\section{Materials and methods}

\section{Data description}

The database used in this paper comes from the World Input-Output Database (WIOD). Dietzenbacher et al. (2013) and Timmer et al. (2015) give detailed description of its compiling methodology: the World Input-Output Table (WIOT). In the country classification of World Input-Output Table, this paper retained China, India, Japan, South Korea, Taiwan, the United States, and the rest of the countries were merged into other countries, and finally the six major countries were analyzed. The carbon dioxide coefficient (C) is calculated by dividing the $\mathrm{CO}_{2}$ emissions of each industry in each country of the 35 sectors in 2013 by the corresponding output value. First, calculate the product input coefficient matrix (D) of each country, and then use the $\mathrm{D}$ coefficient to calculate the $(\mathrm{I}-\mathrm{D})^{\wedge}(-1)$ matrix of domestic correlation table, and calculate the value-added rate (V), then finally perform empirical analysis. Since the Socio Economic Accounts in the WIOD database has not published the 2016 carbon dioxide coefficient data conforming to the new 56-sector classification, so the 56-sector coefficients were not corresponded to the 35-sector classification.

\section{Methods}

There are two main methods used to analyze the driving factors of carbon emission growth in the existing literature: Index Decomposition Analysis (IDA) and Structural Decomposition Analysis (SDA) (Hoekstra and van den Bergh, 2003). Some scholars have summarized IDA (Ang, 1995, 2004; Xu and Ang, 2013); and SDA (Rose and Casler, 1996; Su and Ang, 2012). In this paper, based on the results of Liu et al. (2016) that carbon dioxide emissions are closely related to export production, the first is to understand the Input-output analysis (IOA), which is a method of accounting account presentation, and the model building method depends on the input-output table of the country or region. A country's input-output (IO) table shows the flow of inventory and services, while since IO tables have a clear showing of the life cycle of an industry, the relationship between producers and consumers is related to the production chain of entire economy. By taking into account the impact of the entire supply chain IOA, the EIO model is used to estimate specific emissions from trade, thus the estimation formula of $\mathrm{CO}_{2}$ emissions from national-level export is as follows:

$$
\mathrm{CO}_{2 \exp }=\mathrm{C} \cdot(I-A)^{-1} \cdot \mathrm{e}
$$

where:

$\mathrm{CO}_{2 \exp }=$ Total carbon dioxide emissions representing the specific exports;

$\mathrm{c}=1 \times \mathrm{n}$ rows of carbon dioxide emissions, which is the carbon dioxide emissions per unit of economic output;

$A=$ Intermediate input of total output in the $n \times n$ input coefficient matrix with the division by sectors;

$(I-A)^{-1}=$ Leontief inverse matrix representing the complete induced output matrix produced by a unit; 
$\mathrm{e}=\mathrm{n} \times 1$ rows of vectors representing exports.

According to the different views on supply chain, exports at the emissions sector level can be tracked from upstream to downstream $(D \rightarrow U)$ or from upstream to downstream $(U \rightarrow D)$ :

$$
\begin{aligned}
& C O_{2 \exp }^{D \rightarrow U}=\mathrm{C} \cdot(I-A)^{-1} \cdot \operatorname{diag}(e) \\
& C O_{2 \exp }^{U \rightarrow D}=\operatorname{diag}(c) \cdot(I-A)^{-1} \cdot e
\end{aligned}
$$

In the traditional IO theory, the above two different measures have their own economic explanations, and play different roles in economic analysis. $\mathrm{CO}_{2 \exp }^{D \rightarrow U}$ indicates the carbon dioxide emissions emitted by all industries for exporting certain specific products. In other words, this measure can check the emissions from all the sectors directly or indirectly affected by domestic upstream supply chains. In contrast, $\mathrm{CO}_{2 \exp }^{U \rightarrow D}$ represents the $\mathrm{CO}_{2}$ emissions of a specific sector's specific export. That is to say, this measure depends on how to show the emissions from specific upstream sectors will affect the final exports of all downstream industries.

Finally, according to the definition, there is no difference between the two measures in $\mathrm{CO}_{2}$ emissions at national level in terms of export. If we replace imported wealth goods with a ratio $\mathrm{v}$ of added value relative to output, to estimate the direct and indirect impact of exports on domestic added value. The following formula can be used to calculate the value-added ratio $\mathrm{v}$ of an export product (a $1 \times \mathrm{n}$ vector representing each value-added unit by sector). The so-called entity value-added (GDP) can also be estimated by:

$$
G D P_{\exp }=v \cdot(I-A)^{-1} \cdot \mathrm{e}
$$

Further use of Equations 2 and 3 to represent the carbon indicator $\mathrm{P}$ as emission intensity of export entity can be defined as follows:

$$
\mathrm{P}=\mathrm{CO}_{2 \exp } / G D P_{\exp }
$$

This indicator that indicates the value-added export emissions per unit of a country can therefore be considered as a potential environmental cost for national trade. Display export value-added quotas at the industrial level in the same way:

$$
\begin{aligned}
G D P_{\exp }^{D \rightarrow U} & =v \cdot(I-A)^{-1} \cdot \operatorname{diag}(e) \\
G D P_{\exp }^{U \rightarrow D} & =\operatorname{diag}(v) \cdot(I-A)^{-1} \cdot \mathrm{e}
\end{aligned}
$$

In addition, according to Equation 6, the specific emissions of carbon intensity export at the industrial level are defined as follows:

$$
\begin{gathered}
P^{D \rightarrow U}=C O_{2 \exp }^{D \rightarrow U} / / G D P_{\exp }^{D \rightarrow U}=\left[c \cdot(I-A)^{-1} \cdot \operatorname{diag}(e)\right] / /\left[v \cdot(I-A)^{-1} \cdot \operatorname{diag}(e)\right] \\
P^{U \rightarrow D}=C O_{2 \exp }^{U \rightarrow D} / / G D P_{\exp }^{U \rightarrow D}=c / / v
\end{gathered}
$$


We define "//" as operational symbol of a vector division. It can be seen that the carbon intensity of carbon emissions depends on the input coefficient $c$ and the valueadded rate $\mathrm{v}$ of emissions from all upstream sectors when exporting a specific product, while the carbon emissions of specific sectors are based on the carbon intensity of the production sector (sector emissions/added values), showing that all exports are equal to the conventional definition.

Supposing based on production, the estimation of carbon dioxide emissions depends on the amount of energy used, regardless of the type of industry that uses it. In other words, if different types of industries burn the same amount of specific types of energy, the difference in energy efficiency of the enterprise will be reflected in the energy use per unit of output. This also means that if the traditional IO table does not introduce enterprise heterogeneity and does not change the estimate of production base, thus carbon dioxide emission estimates at the industrial or national level may be different. The use of traditional IO tables can lead to overestimation of $\mathrm{CO}_{2}$ emissions from exports and underestimation of $\mathrm{CO}_{2}$ emissions from domestic final demand, which is mainly because different types of companies have different market shares in traditional IO tables, and neglecting the heterogeneity of enterprises can lead to overestimation of carbon dioxide emissions from exports.

Therefore, this paper replaces the $(I-A)^{-1}$ matrix with the $(I-A)^{-1}$ matrix, where $(I-A)^{-1}$ indicates the direct plus indirect domestic demand coefficient matrix, also known as the domestic industrial correlation matrix. The domestic industrial correlation matrix $(I-A)^{-1}$ is conducted with the sum of vertical and horizontal analysis to obtain the forward and backward correlation degrees of each industry. If the forward and backward correlation degrees are normalized, sensitivity and influence can be obtained. Industries with high forward correlation (sensitivity greater than one) are easy to support downstream industrial production by providing products for downstream industries. Industries with high backward correlation (influence degree greater than one) are easy to drive the development of other upstream industries, and the demand for upstream industrial products is higher. Industries with both high forward and backward correlation degrees as the important industries can drive the development of other industries. Industries with high forward correlation degree and low backward correlation degree can provide the cooperation for the development of other industries. Industries with low forward correlation degree and high backward correlation degree can drive the development of other industries and are not easily affected by other industries. Industries with both low forward and backward correlation degrees are the industries that are not susceptible to other industries and will not drive the development of other industries.

\section{Results}

\section{Main empirical results}

This paper collects data from the new version of WIOD (2000-2014) and the old version (1995-2011) to calculate $\mathrm{CO}_{2}$ emissions, GDP and its intensity (the ratio of $\mathrm{CO}_{2}$ emissions to GDP, that is, $\mathrm{CO}_{2}$ emissions per unit of GDP driven by exports) driven by the total exports of major countries (see Figs. 1 and 4), the intermediate goods (see Figs. 2 and 5) and final goods (see Figs. 3 and 6). 


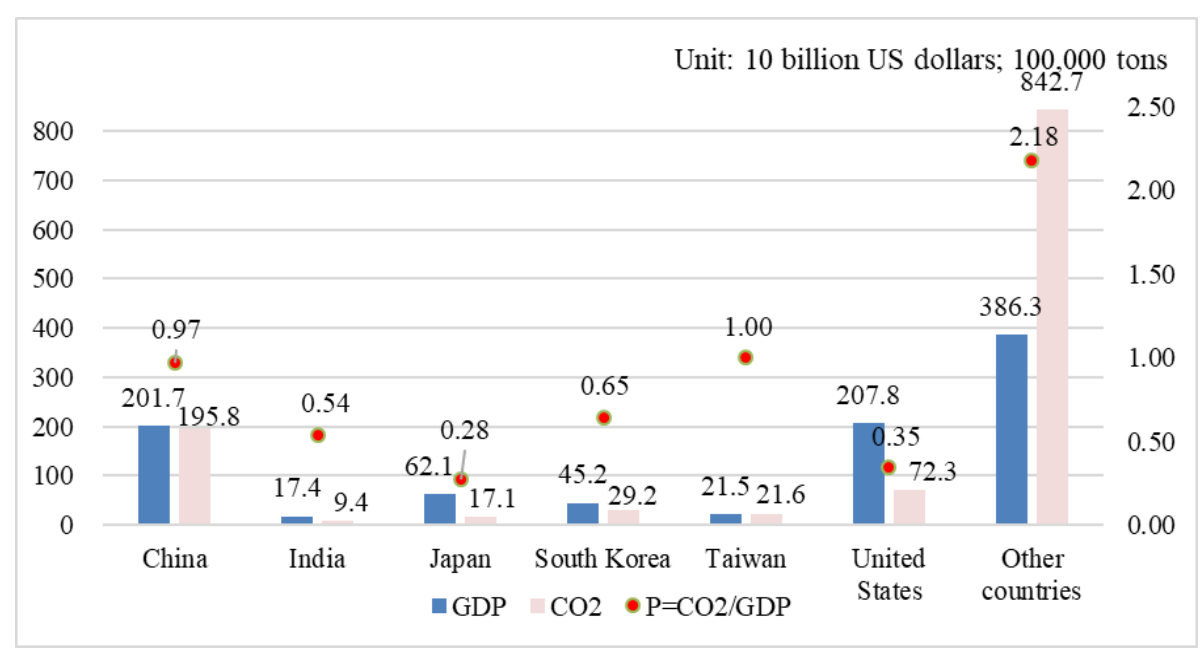

Figure 1. $\mathrm{CO}_{2}$ emissions, GDP and its intensity driven by total exports of countries in 2014 (new version)

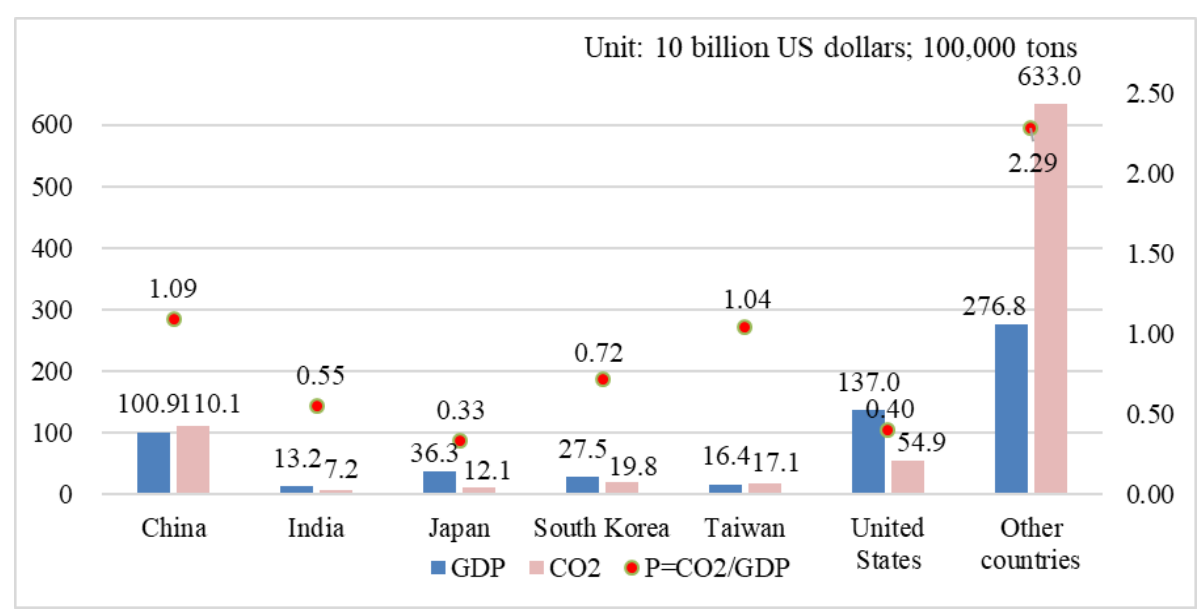

Figure 2. $\mathrm{CO}_{2}$ emissions, GDP and its intensity driven by intermediate goods exports of countries in 2014 (new version)

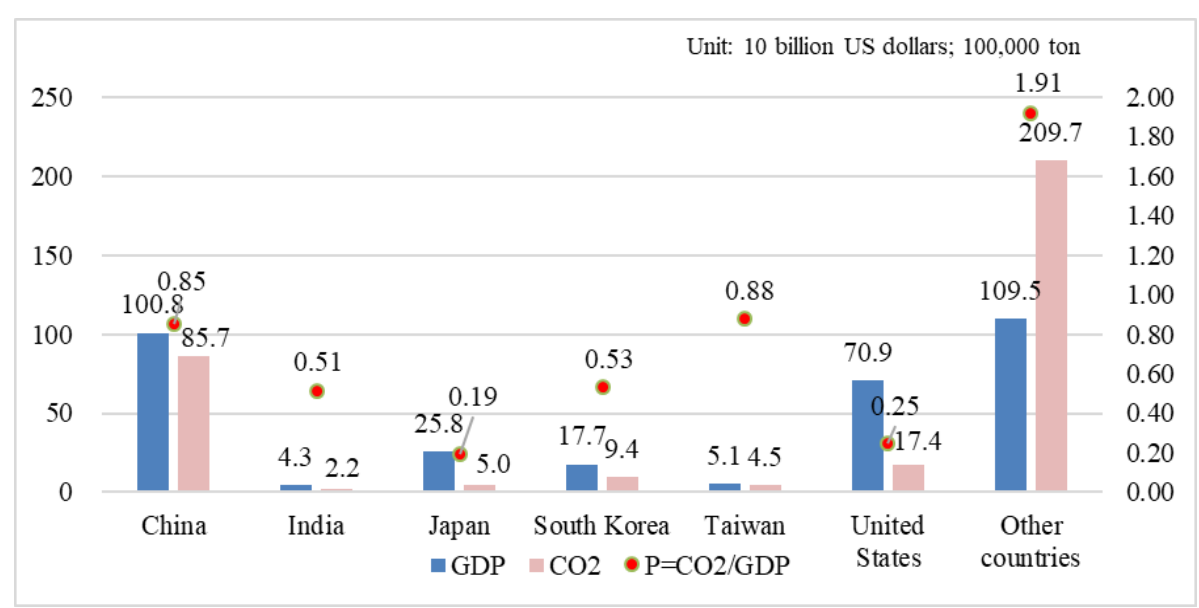

Figure 3. $\mathrm{CO}_{2}$ emissions, GDP and its intensity driven by final goods exports of countries in 2014 (new version) 


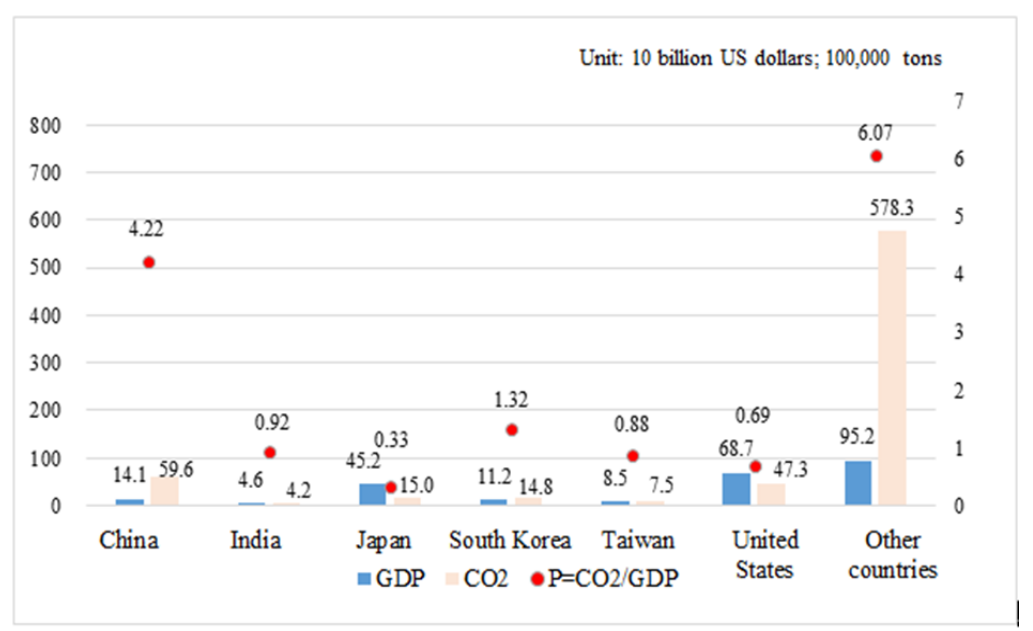

Figure 4. The export level and intensity of total $\mathrm{CO}_{2}$ emissions and GDP in 1995 (old version)

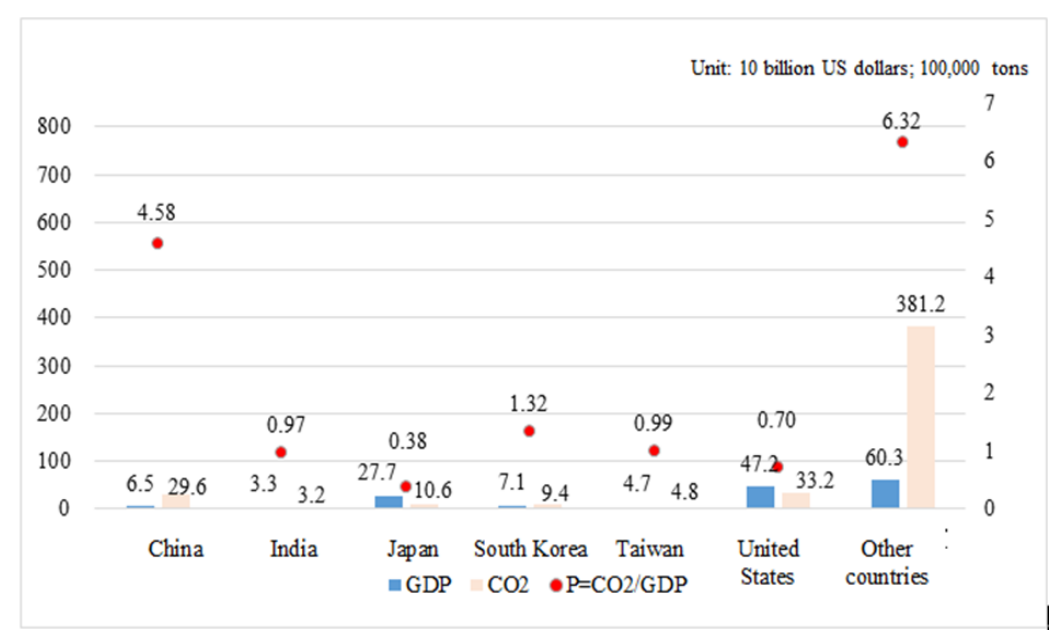

Figure 5. The export level and intensity of total $\mathrm{CO}_{2}$ emissions and intermediate goods-driven GDP in 1995 (old version)

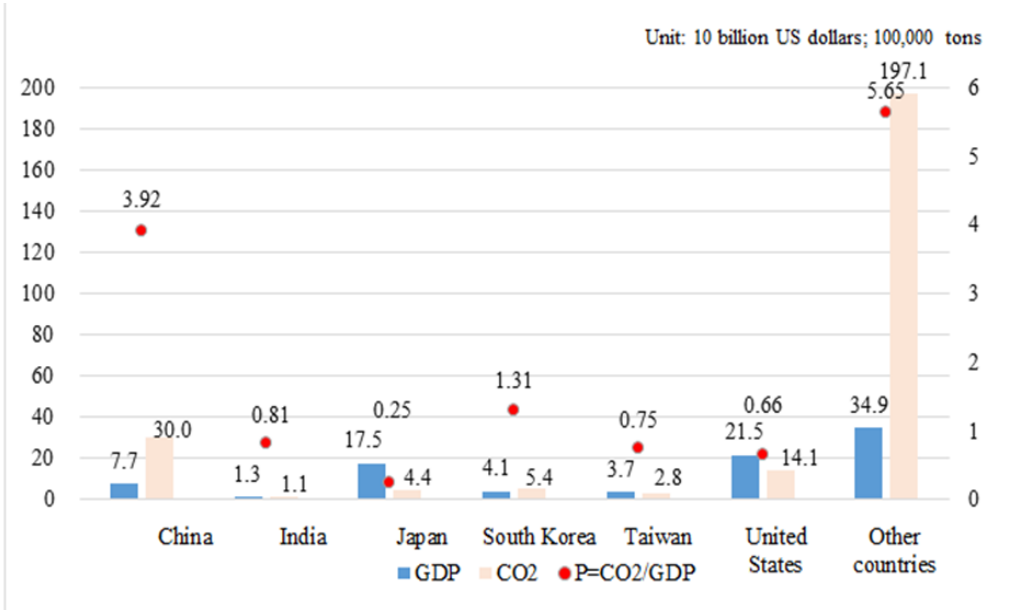

Figure 6. The export level and intensity of total $\mathrm{CO}_{2}$ emissions and final goods-driven GDP in 1995 (old version) 
Figure 1 shows the $\mathrm{CO}_{2}$ emissions, GDP and its intensity driven by total exports of countries in 2014 (new version). China ranks second with $\mathrm{CO}_{2}$ emission intensity of 0.97 in various countries, including $\mathrm{CO}_{2}$ emissions of 19.58 billion tons. Figures 2 and 3 show that the $\mathrm{CO}_{2}$ emission intensity of 1.09 driven by China's intermediate goods is greater than the $\mathrm{CO}_{2}$ emission intensity of 0.85 driven by China's final goods, indicating that China's $\mathrm{CO}_{2}$ emissions mainly come from the intermediate goods. Taiwan's $\mathrm{CO}_{2}$ emission intensity driven by total exports is the highest, reaching 1.0, but in fact, Taiwan's $\mathrm{CO}_{2}$ emissions are only 2.1 billion tons, because Taiwan's GDP is only 200 billion US\$, only higher than the last ranking of India's 170 billion US\$. Figures 2 and 3 show that the $\mathrm{CO}_{2}$ emission intensity of 1.04 driven by Taiwan's intermediate goods is greater than the $\mathrm{CO}_{2}$ emission intensity of 0.88 driven by Taiwan's final goods, indicating that Taiwan's main $\mathrm{CO}_{2}$ emissions come from the intermediate goods, and intermediate goods and final goods show a ratio of 3:1, showing that Taiwan is an economy that exports intermediate goods. South Korea, which is similar to Taiwan's industrial pattern, ranks third in terms of its $\mathrm{CO}_{2}$ emission intensity of 0.65 driven by total exports, and its $\mathrm{CO}_{2}$ emissions of 2.9 billion tons is only 800 million tons more than Taiwan, but its GDP is 450 billion US\$. Figures 2 and 3 show that the $\mathrm{CO}_{2}$ emission intensity of 0.72 driven by South Korea's intermediate goods is greater than the $\mathrm{CO}_{2}$ emission intensity of 0.53 driven by South Korea's final goods, indicating that South Korea's main $\mathrm{CO}_{2}$ emissions mainly come from the intermediate goods. Japan's $\mathrm{CO}_{2}$ emission intensity driven by total exports is the lowest, with $\mathrm{CO}_{2}$ emissions of only 1.7 billion tons, but GDP is as high as 620 billion US\$, which is three times that of Taiwan. The $\mathrm{CO}_{2}$ emission intensity of 0.33 driven by Japan's intermediate goods is greater than the $\mathrm{CO}_{2}$ emission intensity of 0.19 driven by Japan's final goods, indicating that Japan's $\mathrm{CO}_{2}$ emissions mainly come from the intermediate goods.

Figure 4 shows the level and intensity of $\mathrm{CO}_{2}$ emissions and GDP total exports in 1995 (old version). China's $\mathrm{CO}_{2}$ emission intensity is 4.22 , which is three times that of South Korea ranking the second, and China's $\mathrm{CO}_{2}$ emissions are 5.9 billion tons, which ranks the first in the six countries, but China's GDP is only 140 billion US\$, only 30 billion US\$ higher than South Korea. Figures 4-6 show that the $\mathrm{CO}_{2}$ emission intensity of 4.58 driven by China's intermediate goods is greater than the $\mathrm{CO}_{2}$ emission intensity of 3.92 driven by China's final goods, indicating that in 1995, China was still an intermediate goods-oriented country. Taiwan's $\mathrm{CO}_{2}$ emission intensity is 0.88 , ranking the fourth among the six countries, with $\mathrm{CO}_{2}$ emissions of 700 million tons and GDP of 80 billion US\$. The $\mathrm{CO}_{2}$ emission intensity of 0.99 driven by Taiwan's intermediate goods is greater than the $\mathrm{CO}_{2}$ emission intensity of 0.75 driven by Taiwan's final goods, indicating that in 1995, Taiwan was still an intermediate goods export-oriented country. South Korea's $\mathrm{CO}_{2}$ emission intensity is 1.32, ranking the second among the six countries, with $\mathrm{CO}_{2}$ emissions of 1.4 billion tons and GDP of 110 billion US\$. Figures 5 and 6 show that the $\mathrm{CO}_{2}$ emission intensity of 1.32 driven by South Korea's intermediate goods is much the same as the $\mathrm{CO}_{2}$ emission intensity of 1.31 driven by South Korea's final goods, indicating that in 1995, South Korea's export is complemented by intermediate goods and final goods. Japan's $\mathrm{CO}_{2}$ emission intensity of 0.33 is almost the same as that of 2014, with $\mathrm{CO}_{2}$ emissions of 1.5 billion tons and GDP of 450 billion US\$. Figures 5 and 6 show that the $\mathrm{CO}_{2}$ emission intensity of 0.38 driven by Japan's intermediate goods is much the same as the $\mathrm{CO}_{2}$ emission intensity of 0.25 driven by Japan's final goods, indicating that in 1995, Japan was an intermediate goods export-oriented country. 


\section{Discussion}

\section{Analysis and comparison of export-driven $\mathrm{CO}_{2}$ emission intensity in countries in 1995 and 2014}

By comparing the level and intensity of $\mathrm{CO}_{2}$ emissions and GDP driven by total exports of countries in 1995 and 2014 (see Figs. 4 and 1), we can see the rankings of $\mathrm{CO}_{2}$ emission intensity in 1995 were: China, South Korea, India, Taiwan, the United States and Japan; rankings in 2014 were: Taiwan, China, South Korea, India, the United States and Japan. Taiwan rose from the fourth place to the first place, China, South Korea, and India all ranked down, and the United States and Japan ranked the same. In most countries, the level of $\mathrm{CO}_{2}$ emissions has declined, except for Taiwan, and Japan which has low intensity. It has shown that Taiwan has grown with the same proportions of $\mathrm{CO}_{2}$ and GDP in the past 20 years, but other developed countries have doubled.

\section{Analysis of export-driven $\mathrm{CO}_{2}$ emission paths}

In order to concrete our results, Figures 7-10 compare the $\mathrm{CO}_{2}$ emissions in each industry and Table 2 list the industry category and the definition. If we track from downstream industry to the upstream industry $(\mathrm{D} \rightarrow \mathrm{U})$, and from upstream to downstream $(\mathrm{U} \rightarrow \mathrm{D})$, the $\mathrm{CO}_{2}$ emissions driven by the export of each country are observed, and the carbon dioxide emission paths of the industries in Taiwan are organized, as shown in Figures 7 and 8, where, $\mathrm{CO}_{2 \exp }^{D \rightarrow U}$ indicates the carbon dioxide emissions emitted by all industries exporting specific products, which can be used to check the emissions of all sectors directly or indirectly affected by the domestic upstream supply chain, while $C O_{2 \exp }^{U \rightarrow D}$ indicates the carbon dioxide emissions emitted by specific exports from particular sectors, and it can show how the emissions from specific upstream sectors affect the final exports of all downstream industries.

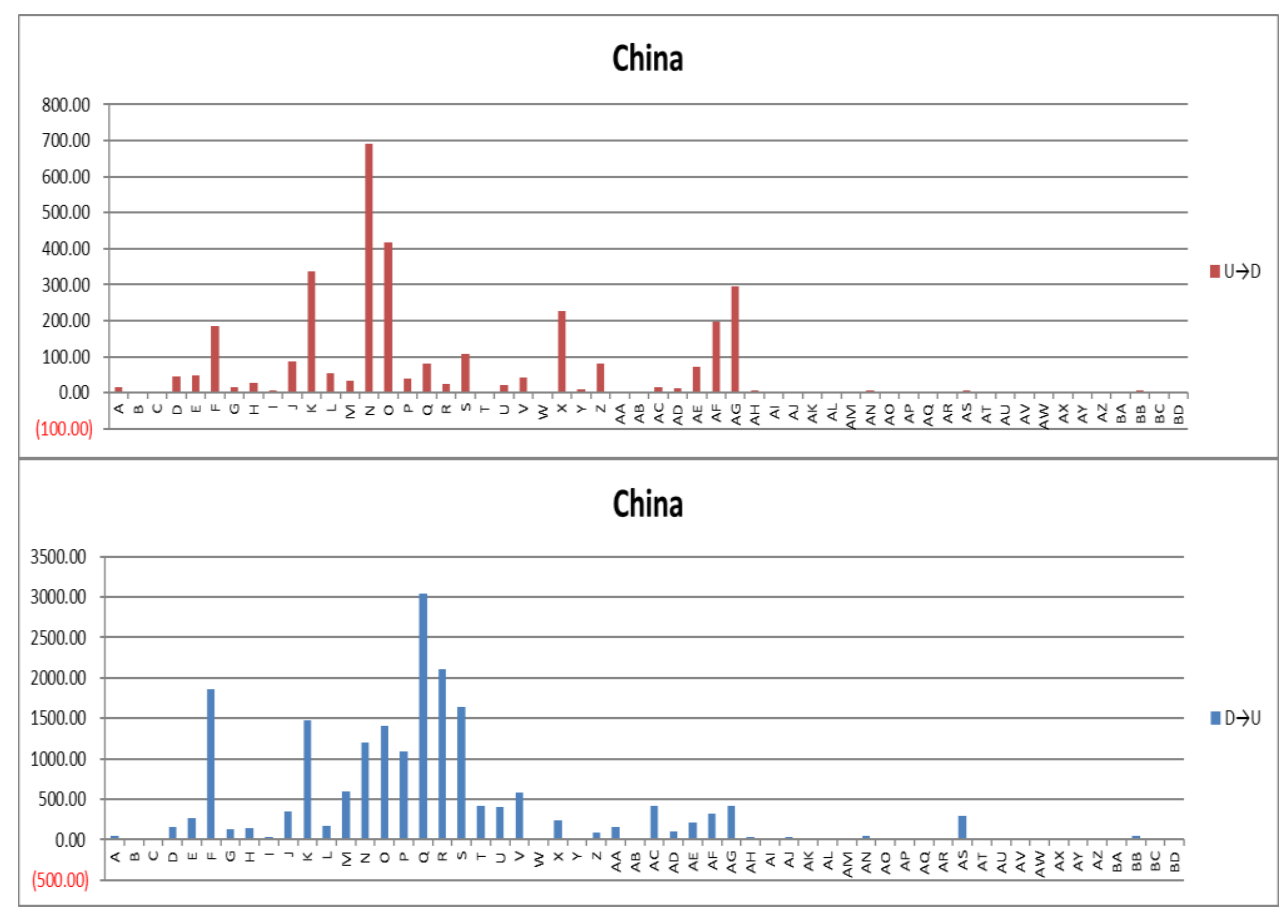

Figure 7. $\mathrm{CO}_{2}$ emissions driven by China's exports in 2014: tracking from the downstream industry to the upstream industry $(D \rightarrow U)$ and from upstream to downstream industry $(U \rightarrow D)$ 


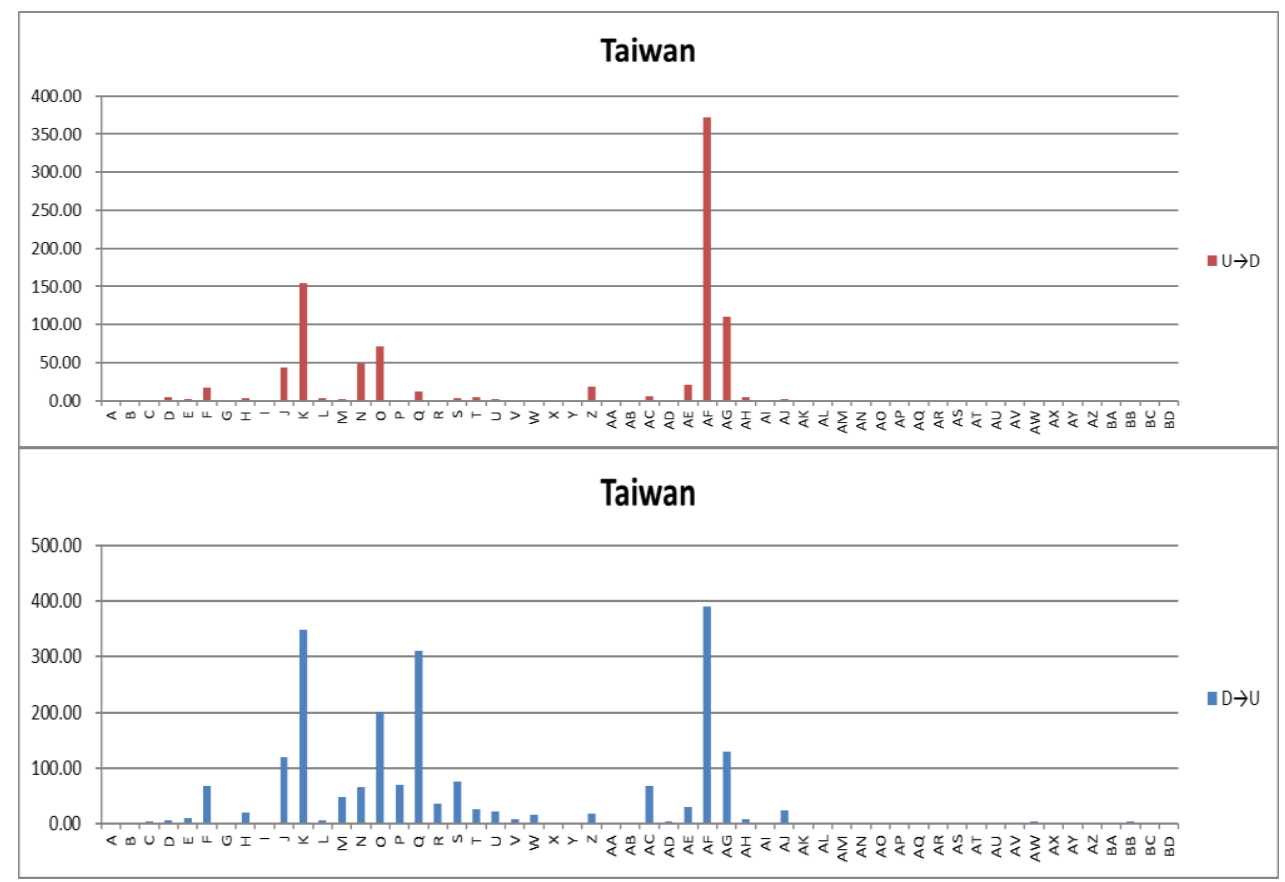

Figure 8. $\mathrm{CO}_{2}$ emissions driven by Taiwan's exports in 2014: tracking from the downstream industry to the upstream industry $(D \rightarrow U)$ and from upstream to downstream industry $(U \rightarrow D)$

Table 2. Industry category and the definition in Figures 7-10

\begin{tabular}{c|c}
\hline Category & Definition \\
\hline A & Crop and livestock products \\
B & Forestry logging \\
C & Fishing aquaculture \\
D & Mining \\
E & Food and beverage \\
F & Textile and apparel \\
G & Wooden products \\
H & Paper products \\
I & Print and copy \\
J & Coal petroleum products \\
K & Chemical products \\
L & Drug products \\
M & Rubber plastic products \\
N & Non-metallic mineral products \\
O & Metal products \\
P & Transportation equipment manufacturing \\
Q & Car trailer manufacturing \\
R & Mechanical equipment manufacturing \\
S & Furniture manufacturing \\
T & Electronic optical products \\
U & Electrical equipment manufacturing \\
V & Manical equipment repair and installation \\
W & Meducts (except equipment) \\
\hline & Mechal \\
\hline
\end{tabular}




\begin{tabular}{|c|c|}
\hline $\mathrm{X}$ & Electricity-fired fluorine air conditioner supply \\
\hline $\mathrm{Y}$ & Water collection and treatment supply \\
\hline $\mathrm{Z}$ & Waste recycling management \\
\hline AA & Construction \\
\hline $\mathrm{AB}$ & Trade and repair of automobiles and locomotives \\
\hline $\mathrm{AC}$ & Wholesale trade (except automobiles and locomotives) \\
\hline $\mathrm{AD}$ & Retail (except automobiles and locomotives) \\
\hline $\mathrm{AE}$ & Land pipeline transportation \\
\hline $\mathrm{AF}$ & Water transport \\
\hline AG & Air transport \\
\hline $\mathrm{AH}$ & Warehousing and transportation \\
\hline AI & Post Express \\
\hline AJ & Accommodation activities \\
\hline AK & Publishing \\
\hline $\mathrm{AL}$ & Audio and video production and publishing \\
\hline $\mathrm{AM}$ & Telecommunications \\
\hline AN & Computer program consulting related \\
\hline $\mathrm{AO}$ & Financial services (excluding insurance) \\
\hline AP & Insurance (except compulsory insurance) \\
\hline AQ & Financial and insurance assistance \\
\hline AR & Real estate \\
\hline $\mathrm{AS}$ & Legal and accounting advice related \\
\hline $\mathrm{AT}$ & Construction engineering analysis \\
\hline $\mathrm{AU}$ & Scientific research development \\
\hline AV & Advertising and market research \\
\hline AW & Other science and technology related to veterinary counseling \\
\hline $\mathrm{AX}$ & Administrative service related \\
\hline AY & Public administration and compulsory insurance \\
\hline AZ & Education \\
\hline BA & Health and social activities \\
\hline $\mathrm{BB}$ & Other social activities \\
\hline $\mathrm{BC}$ & Family (for domestic use) \\
\hline $\mathrm{BD}$ & Related activities of overseas institutions \\
\hline $\mathrm{BE}$ & Leather product \\
\hline
\end{tabular}

As shown in Figures 4-7, the $\mathrm{CO}_{2}$ emissions driven by China's exports are tracked from the downstream industry to the upstream industry $(\mathrm{D} \rightarrow \mathrm{U})$, that is, $\mathrm{CO}_{2}$ emissions produced from the input of upstream industry because of the other industries driven by export products, see left bar of Figures 4-7. China's major downstream export industry sectors are electronic optical products (300 million tons), electrical equipment manufacturing (210 million tons), textile and apparel (180 million tons), transportation equipment manufacturing (160 million tons). The $\mathrm{CO}_{2}$ emissions driven by China's exports are tracked from the upstream industry to the downstream industry $(\mathrm{U} \rightarrow \mathrm{D})$ to track the upstream industry, which is to support the $\mathrm{CO}_{2}$ emissions generated by the downstream industries, see the right bar of Figures 4-7. The upstream-supported export 
industry sectors are mainly non-metallic mineral products (70 million tons), metal products (40 million tons), and chemical products (30 million tons).

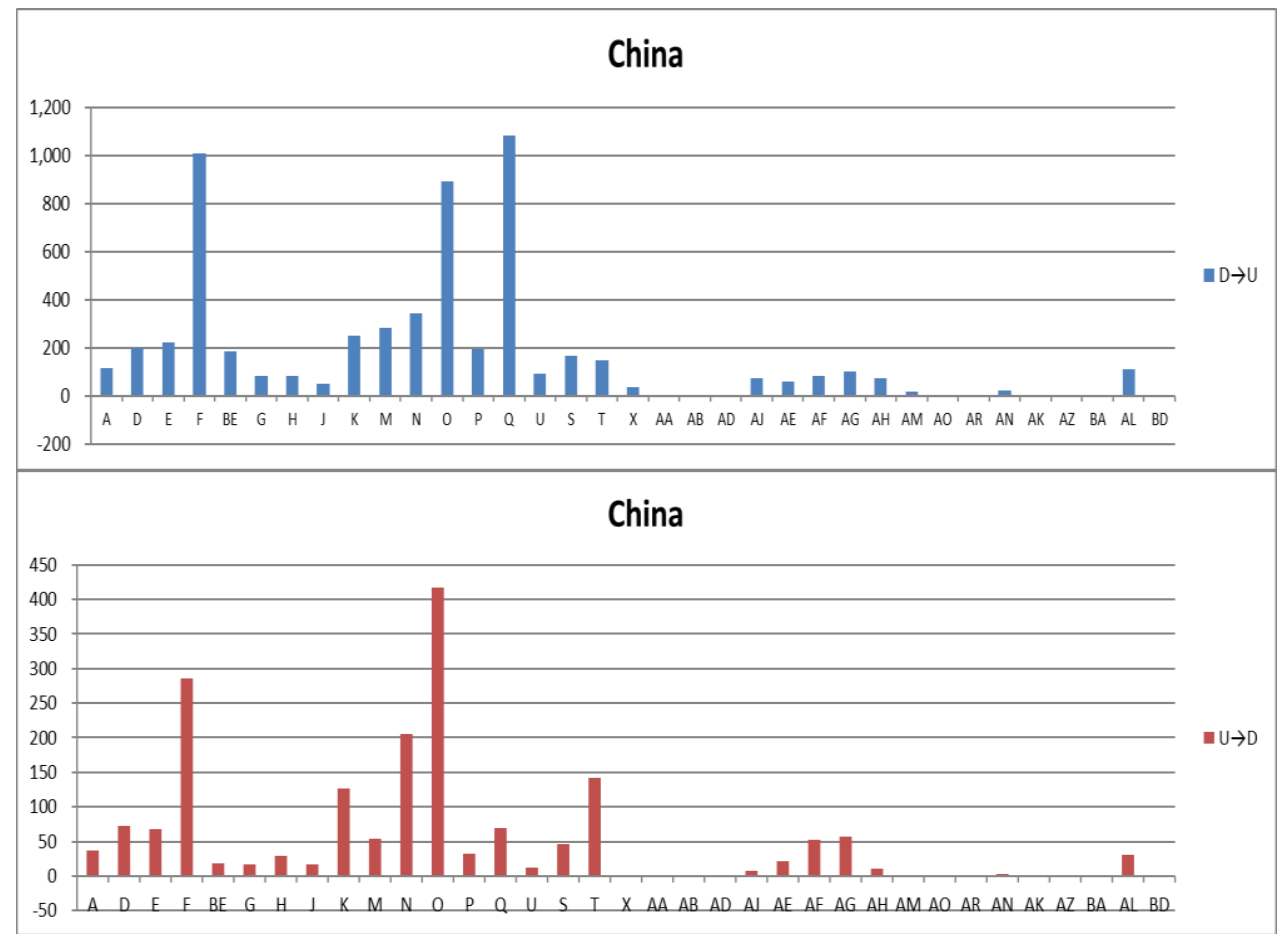

Figure 9. $\mathrm{CO}_{2}$ emissions driven by China's exports in 1995: tracking from the downstream industry to the upstream industry $(D \rightarrow U)$ and from upstream to downstream industry $(U \rightarrow D)$

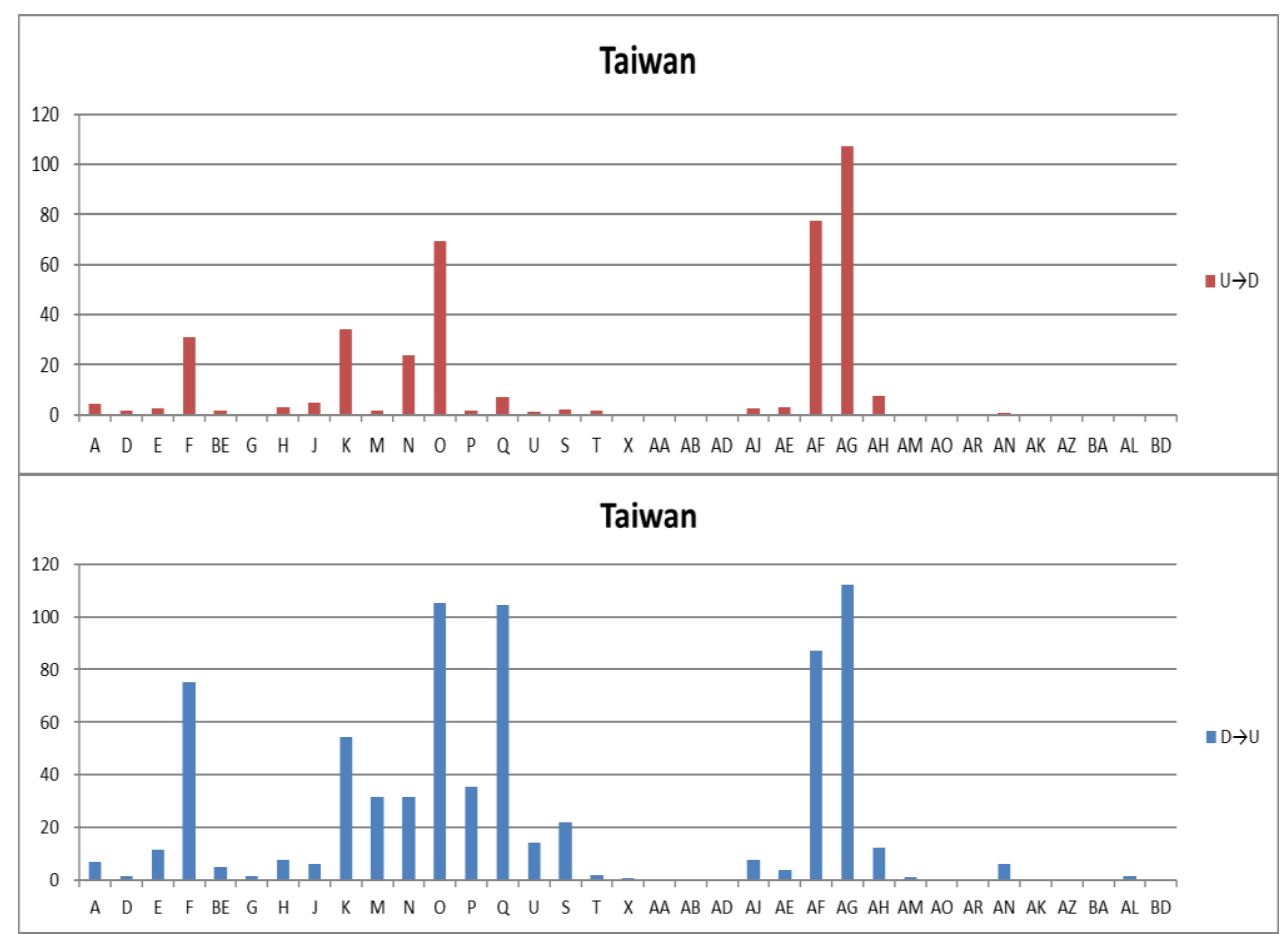

Figure 10. $\mathrm{CO}_{2}$ emissions driven by Taiwan's exports in 1995: tracking from the downstream industry to the upstream industry $(D \rightarrow U)$ and from upstream to downstream industry $(U \rightarrow D)$ 
The $\mathrm{CO}_{2}$ emissions driven by Taiwan's exports are tracked from the downstream industry to the upstream industry $(\mathrm{D} \rightarrow \mathrm{U})$, see the left bar of Figures $4-8$. The major downstream export industry sectors are water transport (about 39 million tons), chemical products (about 35 million tons), and electronic optical products (about 31 million tons). The $\mathrm{CO}_{2}$ emissions driven by Taiwan's exports tracked from upstream industry to downstream industry $(\mathrm{U} \rightarrow \mathrm{D})$ is shown in the right bar of Figures $4-9$. The major industrial sectors invested in the upstream are water transport (about 37 million tons), chemical products (about 15 million tons), and air transport (about 11 million tons).

Finally, Figures 9 and 10 summarize the estimated estimation on $\mathrm{CO}_{2}$ emissions in China and Taiwan in 1995. The $\mathrm{CO}_{2}$ emissions driven by exports from 1995 to 2014 are compared and tracked from the downstream industry to the upstream industry $(\mathrm{D} \rightarrow \mathrm{U})$ and from upstream to downstream industry $(\mathrm{U} \rightarrow \mathrm{D})$ see from Fig 4- Fig 10. In the $\mathrm{CO}_{2}$ emissions driven by China's exports tracked from the downstream industry to the upstream industry $(\mathrm{D} \rightarrow \mathrm{U})$, electronic optical products, textile and metal products have the most emissions, while when tracking from upstream to downstream industry $(\mathrm{U} \rightarrow \mathrm{D})$, the metal products, textile and non-metal products have the most emissions. In 2014, China's major downstream industrial sectors added more high $\mathrm{CO}_{2}$ emissions sectors such as electrical equipment manufacturing, transportation equipment manufacturing and chemical products. In 1995, when $\mathrm{CO}_{2}$ emissions driven by Taiwan's exports are tracked from the downstream industry to the upstream industry $(\mathrm{D} \rightarrow \mathrm{U})$, the air transport, metal products and electronic optical products have the most emissions, while when tracking from upstream to downstream industry $(U \rightarrow D)$, the air transport, water transport and metal products have the most emissions. In 2014, Taiwan's high $\mathrm{CO}_{2}$ emissions sectors are water transport, chemical products and electronic optical products.

\section{Conclusion}

The composition of industrial chains is interdependent in international trade. Today, global trade belongs to different countries in the upper, middle and lower reaches of production process of vertical labor division. This paper analyzes trade items and supply chain portfolios from global value chains, and further integrates and compares the carbon emissions from supply chain portfolios across countries. Based on the results of Liu et al. (2016), this paper uses the EIO model to analyze the relationship between trade exports and carbon dioxide emissions in Taiwan and other six countries. The empirical analysis of this paper first analyzes the $\mathrm{CO}_{2}$ emission intensity driven by countries' exports, where Taiwan's total $\mathrm{CO}_{2}$ emission intensity is 1.0, topping the highest, with $\mathrm{CO}_{2}$ emissions of only 2.1 billion tons, which is caused by Taiwan's low GDP of 200 billion US\$. The $\mathrm{CO}_{2}$ emission intensity driven by China's total exports is 0.97, with $\mathrm{CO}_{2}$ emissions of as high as 19.58 billion tons, but the GDP is 2 trillion US\$, resulting in an intensity of only 0.97 . The $\mathrm{CO}_{2}$ emission intensity driven by the US total exports is only 0.35 , with $\mathrm{CO}_{2}$ emissions of 7.2 billion tons, which is caused by the high US GDP as much as 2.07 trillion US\$. South Korea, which is similar to Taiwan's industrial pattern, has a $\mathrm{CO}_{2}$ emission intensity of 0.65 driven by its total exports, with $\mathrm{CO}_{2}$ emissions of 2.9 billion tons, only 800 million tons more than Taiwan, but the GDP is 450 billion US\$. The total $\mathrm{CO}_{2}$ emission intensity driven by Japan's total exports is 0.28 , with $\mathrm{CO}_{2}$ emissions of only 1.7 billion tons, but the GDP is as high as 620 billion 
US\$, which is three times that of Taiwan. The results of the analysis show that most developed countries take intermediate goods as the main export type under the global industrial chain, while the exports in less developed countries such as India have a ratio of 1:1 between intermediate goods and final goods, and final goods may even count greater than intermediate goods.

By comparing the level and intensity of $\mathrm{CO}_{2}$ emissions and GDP total exports in various regions in 1995 and 2004, we can see that Taiwan rose from the fourth to the first place. China, South Korea and India ranked from the first, second and third to second, third and fourth, respectively, the United States and Japan remain unchanged at the fifth and sixth place. In most countries, the level of $\mathrm{CO}_{2}$ emissions has declined, except for Taiwan, and Japan which has low intensity. It has shown that Taiwan has grown with the same proportions of $\mathrm{CO}_{2}$ and GDP in the past 20 years, but other developed countries have doubled.

Then, if we track from downstream industry to the upstream industry $(D \rightarrow U)$, and from upstream to downstream $(\mathrm{U} \rightarrow \mathrm{D})$, the $\mathrm{CO}_{2}$ emissions driven by the export of Taiwan and mainland are observed, with $\mathrm{CO}_{2}$ emissions produced from the input of upstream industry because of the other industries driven by China's downstream export products, which means that by tracking from downstream to upstream, China's major downstream export industry sectors are electronic optical products, electrical equipment manufacturing, textile and apparel and transportation equipment manufacturing. The upstream industry in China supports the $\mathrm{CO}_{2}$ emissions generated by the downstream industries, that is, by tracing from upstream to downstream, the major upstream sectors supporting export industry are non-metallic mineral products, metal products and chemical products. Taiwan's major downstream export industry sectors are water transport, chemical products and electronic optical products, and the major upstream sectors are water transport, chemical products and air transport.

As China launches the carbon trading market, Singapore is expected to introduce a carbon tax in 2019, and many countries around the world have formulated a policy on carbon pricing. Yet it is uncertain whether the carbon tax will bring a huge burden to the economy, only some countries in northern Europe succeeded in maintaining economic growth rate. On the other hand, Australia has abolished the carbon tax, which became a major cause of dragging down the Australian economy. In Taiwan and other countries in the world, environmental mark and carbon footprint mark are more commonly used, that is, how much carbon is emitted from the product or how much energy is used in the product are clearly marked, so that consumers can choose whether to buy lower-carbon products after reading the message. Energy costs such as the use of fuel may rise from the imposition of emission taxes, while people can transform the society into a sustainable development pattern through the change of lifestyle. This paper is mainly to explore the generation and attribution of $\mathrm{CO}_{2}$ generated by inter-regional economic production and exchange, and to compare the growth rate of $\mathrm{CO}_{2}$ emissions between different economies. In the follow-up, we will further explore the relationship between environmental shocks, foreign trade changes, and commodity substitutions generated by such economic activities.

Acknowledgements. This paper was supported by Major Project of Humanities and Social Sciences in Colleges and Universities in Zhejiang province during the year 2017-2018 (Grant No. 2018QN089), the MOE Foundation of Humanities and Social Sciences (Grant No. 19YJCGJW011), Talent Project by Qianjiang in Zhejiang province (Grant No. QJC1803005). 


\section{REFERENCES}

[1] Ang, B. W. (1995): Decomposition methodology in industrial energy demand analysis. Energy 1: 168-182.

[2] Ang, B. W. (2014): Decomposition analysis for policy making in energy: which is the preferred method? - Energy Policy 32: 1131-1139.

[3] Dietzenbacher, E., Stage, J. (2006): Mixing oil and water? Using hybrid input-output tables in a structural decomposition analysis. - Economic Systems Research 18: 85-95.

[4] Dietzenbacher, E., Los, B., Stehrer, R., Timmer, M. P., de Vries, G. J. (2013): The construction of world input-output tables in the WIOD Project. - Economic Systems Research 25: 71-98.

[5] Hoekstra, R., van den Bergh, J. M. (2003): Comparing structural decomposition analysis and index. - Energy Economics 25: 39-64.

[6] Jin, A. H., Bai, L., Kim, J. Y., Jeong, S. J., Kim, K. S. (2017): Analysis of GHG emission reduction in South Korea using a $\mathrm{CO}_{2}$ transportation network optimization model. Energies 10: 1-18.

[7] Kagawa, S., Inamura, H. (2001): A structural decomposition of energy consumption based on a hybrid rectangular input-output framework: Japan's case. - Economic Systems Research 13: 339-363.

[8] Lenzen, M. (2003): Environmentally important paths, linkages and key sectors in the Australian economy. - Structural Change and Economic Dynamics 14: 1-34.

[9] Lenzen, M., Pade, L. L., Munksgaard, J. (2004): $\mathrm{CO}_{2}$ multipliers in multi-region inputoutput models. - Economic Systems Research 16: 391-412.

[10] Lin, C., Yang, J. (2017): Research on the Technology Spillover Effect of Taiwanese Investment on Agricultural Products Processing Industry in Mainland China. - In: 2017 International Conference on Education Science and Economic Management (ICESEM 2017). Atlantis Press, Paris.

[11] Liu, Y., Mong, B., Hubacek, K., Xue, J., Feng, K., Gao, Y. (2016): Made in China: a reevaluation of embodied $\mathrm{CO}_{2}$ emissions in Chinese exports using firm heterogeneity information. - Applied Energy 184: 11106-1113.

[12] Lu, M. (2018): Introduction: The Changing Geographies of China. - In: Li, S. et al. (eds.) Changing China. Routledge, Abingdon, pp. 1-13.

[13] Meng, B., Fang, Y., Guo, J., Zhang, Y. (2017): Measuring China's domestic production networks through trade in value-added perspectives. - Economic Systems Research 29(1): 48-65.

[14] Peter, G. P., Hertwich, E. G. (2006): Structural analysis of international trade: environmental impacts of Norway. - Economic Systems Research 18: 155-181.

[15] Rigger, S. (2015): Taiwanese Business in Mainland China: From Domination to Marginalization? - In: Irwin Crookes, P., Knoerich, J. (eds.) Cross-Taiwan Strait Relations in an Era of Technological Change (pp. 61-76). Palgrave Macmillan, London.

[16] Ritchie, H., Reay, D., Higgins, P. (2018): Sustainable food security in India-Domestic production and macronutrient availability. - PloS One 13(3): e0193766.

[17] Rose, A., Casler, S. (1996): Input-output structural decomposition analysis: a critical appraisal. - Economic Systems Research 8: 33-62.

[18] Su, B., Ang, B. W. (2012): Structural decomposition analysis applied to energy and emissions: some methodological developments. - Energy Economics 34: 177-188.

[19] Timmer, M. P., Dietzenbacher, E., Los, B., Stehrer, R. de Vries, G. J. (2015): An illustrated user guide to the world input output database: the case of global automotive production. - Review of International Economics 23: 575-605.

[20] Xu, X. Y., Ang, B. W. (2013): Index decomposition analysis applied to $\mathrm{CO}_{2}$ emission studies. - Ecological Economics 93: 313-329. 